\title{
...La Bella e Agile sua Voce
}

\author{
Antonio Luis Cagnin
}

Sua voz ressoava ainda no Salão da Concórdia Paulistana... e na voz do povo.

Foi no domingo, 27 de setembro de 1862 ! Cartazes em frente ao Concórdia e, certamente, em todas as esquinas das ruas estreitas da cidadezinha haviam-lhe anunciado, com letras garrafais, 0 grande concerto. Uma prima donna!' O pequeno lugarejo a teria ouvido, deslumbrado! Os jornais noticiavam antecipando-lhe o sucesso:

\section{CONCERTO}

Tem logar hoje no salão da Concordia Paulistana o concerto offerecido aos amadores por Mme. Rachel de Almeida.

A reputação da illustre cantora, já bem conceituada nos theatros de Roma, da Hespanha e de outros logares da Europa, dá-nos o direito a crer que a noite será passada entre torrentes de harmonia, derramando-se em ondas de luz e inebriando os ouvidos com o aroma celeste da música divina.

Mme. Rachel de Almeida arrebatou as grandes platéias do mundo com o mellifluo trinar de sua voz candente e sonora. Filha da Itália, desse canto sublime, que o Creador soltou personificando a imagem da glória e o symbolo da poesia, viveu pela magia da arte e entrou nos vastos sallóes formando o cortejo vencedor de Lagrange e Stoltz ${ }^{2}$, os dous anjos baptizados nas fontes do céu 
pelas mãos de Deus. Esperamos do público de S. Paulo uma recepção compativel com o elevado conceito e os talentos acrysolados de Mme. Rachel de Almeida. ${ }^{3}$

$\mathrm{O}$ concerto de Mme. Raquel ${ }^{4}$ certamente foi um grande sucesso, a julgar pelos elogios grandiloqüentes que the teceu o jornal antes mesmo de sua realização. A comparação com as divas do bel canto, La Grange e Stoltz, que levavam ao delírio o "selecto" público do Rio de Janeiro, bem mostra o orgulho dos paulistas, que agora já podiam contar também com uma prima donna ao nível daquelas duas estrelas da Corte.

Pelo que se pôde constatar nos registros de jornais da época, nunca a capital da Província ouvira antes uma cantora que, à semelhança de Mme. Raquel, tivesse arrebatado as platéias da Europa. Grandes companhias líricas visitavam com freqüência a capital do Império, mas nenhuma aportara em Santos nem enfrentara o íngreme e desconfortável Caminho de Anchieta, serpenteando pela Serra do Mar rumo ao planalto; a ópera nunca lhe fora possível, faltavam-lhe certamente uma orquestra e um elenco de vozes à altura do grande espetáculo. Apenas alguns trechos ensaiaram conquistar o gosto da platéia provinciana em dois concertos ${ }^{5}$ que antecederam, de alguns meses apenas, ao de Mme. Raquel, quando toda a família Lago cantou o coro da ópera Nabucodonosor, de Verdi, e uma passagem da Noite no Castelo, que Carlos Gomes acabara de compor. Aplausos à familia Lago, mas o entusiasmo e os comentários pararam aí. Talvez em força do provérbio, a prata da casa dificilmente poderia arrastar o público a se interessar e adquirir o gosto pelo canto lírico e pelas óperas. Ferreira de Meneses, mencionando aqueles tempos, afirmava em O Ypiranga, em 1869, que "os paulistas, em matéria de música, eram capazes de assar um rouxinol e comê-lo"6.

Nessa época - estávamos em 1862 -, o repertório não lhe ultrapassava o das modinhas populares, dos cantos religiosos e das langorosas serenatas românticas dos estudantes da Academia de Direito. 
Viajantes estrangeiros, de passagem pela Província em diversas épocas, no entanto, documentam o contexto e as pouco exigentes aspirações musicais dos tempos que antecederam o concerto de Raquel.

Para Martius, que a visitou em 1817-18, a música era ainda "caótica à busca dos seus elementos primitivos". Além do violão para acompanhamento, o alemão se embalou ao "canto das paulistas: todo singeleza e ingenuidade. A voz se casava bem à expressão dos idílios poéticos" e a modinha brasileira, pela naturalidade do texto e da melodia, pelos versos, pela toada, devia ter feito devanear um pouco aquele romântico sensível que sempre transparece em meio às frias e precisas observações do naturalista?.

Saint-Hilaire narra que, num jantar a convite do governador Oeyenhausen em 4 de novembro de 1819, "a música do regimento", que estava à porta do salão, "executou uma marcha de guerra" à hora do brinde. Os bailes não falhavam em complemento a esses banquetes, como aconteceu também noutra festa: "a orquestra: começou a usar os seus instrumentos em música de dança": a française era então desconhecida, dançava-se tão somente a écossaise (schottisch) importada da Europa; tinha-se ouvido falar da valsa alemã, mas o fato de abraçar as damas era tido por inconveniente ${ }^{8}$.

Kidder, entre 1840 e 1850 , testemunhou cantos em situação diferente, quando passou alguns dias na fazenda Jaraguá, de Dona Gertrudes (Lacerda Jordão), rica senhora, dona de várias fazendas, "que residia numa das melhores casas da cidade". O jantar era servido pelas seis horas. A ceia, às nove. "Durante a noite meia hora era consagrada à oração. Vimos grande número de negros que entravam e uns após outros nos saudavam, mãos cruzadas sobre o peito, com a jaculatória - Louvado seja Nosso Senhor Jesus Cristo. Depois começaram a cantar no quarto contíguo... A devoção dessa tarde consistia principalmente em uma novena... era realmente agradável ouvir a combinação de uma centena de vozes nesses piedosos exercícios" $"$ 
Cernicchiaro afirma - mas sem citar fonte nem data, provavelmente pelos meados da década de 40 - que La Candiani ${ }^{10}$, a primeira e mais famosa diva do bel canto a enfeitiçar o público da Corte, em turnê "pelas províncias com um grupo de atores, depois de penosa viagem teria passado por São Paulo". Cantando "trechos da Sonâmbula e da Norma, com sua voz sedutora", obteve um grande sucesso. Taubaté também fora ao delírio, tal que, reunindo-se todos os amadores da cidade, formou-se uma pequena orquestra sem outra compensação que o de prestar homenagem a tão grande artista.

Mais próximo do tempo em que Mme. Raquel se apresentou, Álvares de Azevedo se encantava com o baile acadêmico de 11 de agosto de 1849: "É na verdade uma idéia singular a dos estudantes de festejar esse dia com folias de baile, e as bandejas de doce das salas e $o$ champagne do botequim". Não dançou mas ficou a admirar as lindas mulheres, especialmente a Bela, filha da Marquesa de Santos: "A condessa de Iguassú e a Belisária eram as rainhas do baile, com a diferença que a Belisária com a simplicidade do seu traje estava mais bonita que a Bela com a sua riqueza de jóias e sedas. A Bela tinha um vestido cinzento que lhe fazia uma cinturinha de sílfide. - No colo numa volta só lhe corria o colar de finíssimas, digo grossíssimas pérolas. - Não havia dizer se as pérolas aí eram o enfeite ou o enfeitado. Na cabeça prendendo as tranças tinha um pequenino boné ...ga, cujo fundo era de rede de prata e em franja também de prata, ... colo, na cintura, no bouquet exalavam-lhe perfumosos ramos de plantas. "Mais tarde, retomando seu acre pessimismo, lamentava: "Nunca vi lugar tão insípido como hoje está São Paulo. Nunca vi coisa tão tediosa e mais inspiradora do spleen... a vida é um bocejar infinito... não há passeios que entretenham, nem bailes, nem sociedades, parece isto uma cidade de mortos. Falei-lhe na Filarmônica. Lá estive - em geral cantam sofrivelmente mal as minhas patrícias - exceto a Mariquinhas Gomide, que canta alguma cousa bem, e dá uns arremedos de Candiani... e uma filha da Chiquinha (uma menina de 12 anos) que promete ser uma ótima voz, uma voz muito afinada, e além disso, muito doce". E profetizava: 


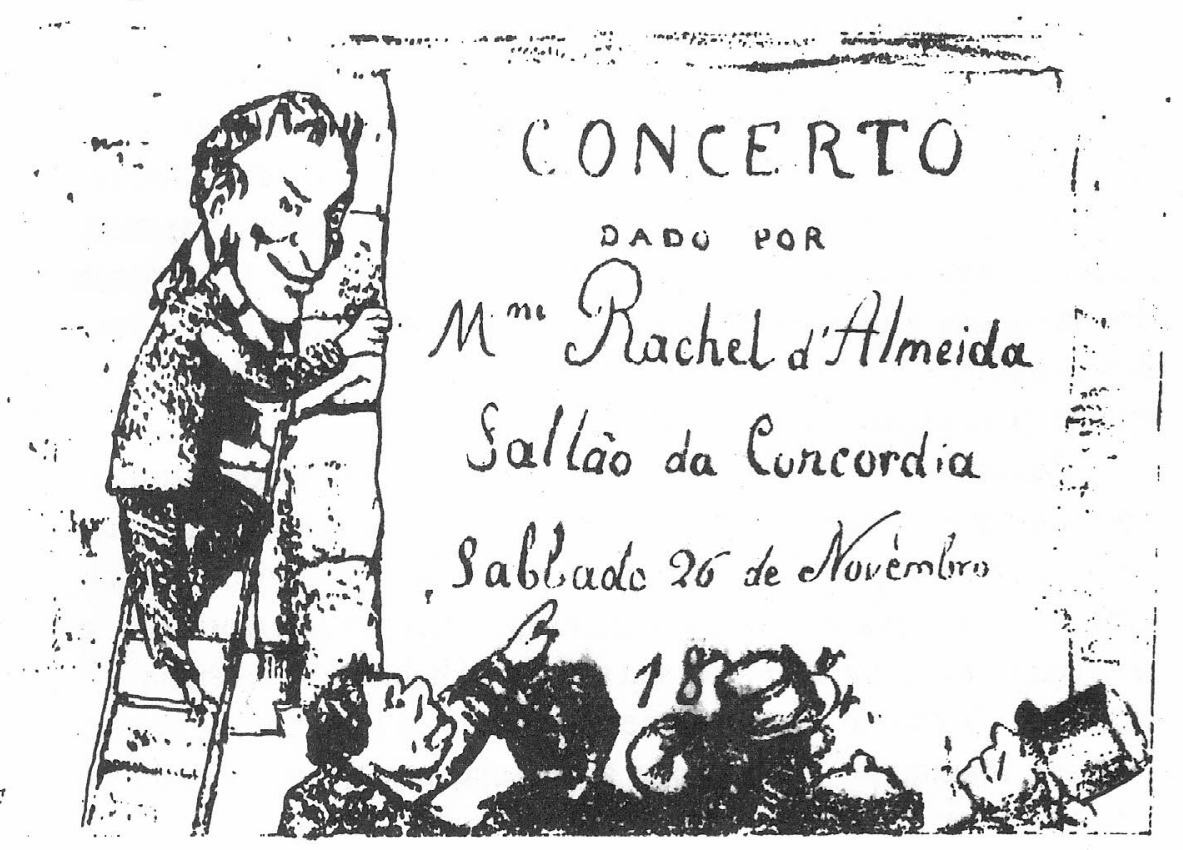
Anúncio do Concerto de M.me Raquel Agostini de Almeida em 26 de novembro de 1864 , em desenho
de Ângelo Agostini, seu filho (Cfr. jornal Dlabo Coxo, $n^{\circ} 8$, s.d. (20nov1864), pág. 8 (11 x 16cm).

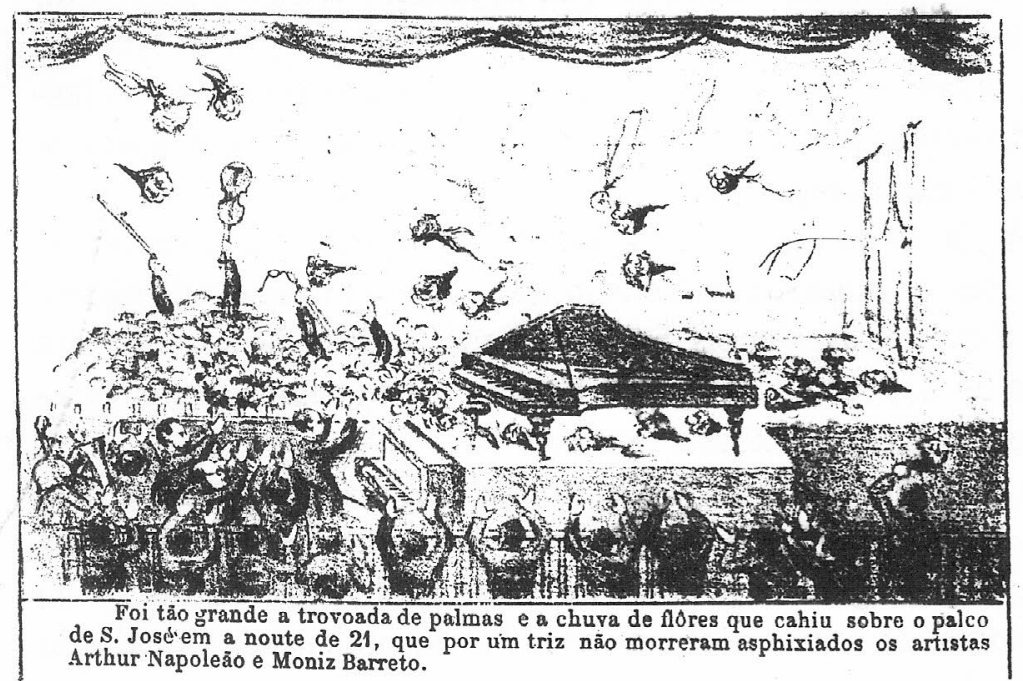


- "São Paulo nunca será como o Rio!"

Perdida nos altos campos de Piratini, vinte mil almas, pouco menos ou mais, edificios pequenos, igrejas pobres, casas de taipa, telhados coloniais enegrecidos pelo tempo, rótulas entreabertas donde mulheres retraídas espiavam curiosas o movimento das ruas; noites tranqüilas, sem sobressaltos, vigiadas pela luz preguiçosa dos lampiões a querosene, embaladas pelas serenatas românticas dos acadêmicos, a cidade se espreguiçava sonolenta, despertada apenas pela algazarra de estudantes.

Zaluar, em 1860, frisava o papel representado pelos estudantes, na pequena capital da Província, "monótona, quase desanimada: a mocidade acadêmica imprime à povoação, durante a sua residência, uma espécie de vida fictícia, que, apenas interrompida, a faz recair, por assim dizer, no seu estado de habitual sonolência". E sintetiza: "Tirem a Academia de São Paulo, e esse grande centro morrerá inanimado"12. É o que acontecia, nas férias, quando os estudantes em debandada deixavam a Academia e São Paulo.

Para Almeida Nogueira, por volta de 1840 a 1850 , era ainda uma pequenina e modesta cidade provinciana de tristonho aspecto, sem movimento, sem animação, de população retraída, sobretudo em relação aos forasteiros, esquivas as damas que pouco apareciam na cidade e escassamente ornavam com suas presenças as festas e diversões públicas, mais raras, aliás, que as raríssimas senhoras que a elas compareciam. Bailes pouquíssimos ${ }^{13}$.

A planta do centro da cidade, de 1854, indica os seus estreitos limites, a antiga rua da Constituição, depois Florêncio de Abreu, a rua das Freiras, depois Senador Feijó, a descida do Açu, ora ladeira de S. João, e o largo do Palácio. Além desses limites estavam as chácaras, várzeas e campos.

Longe de tudo e de todos, um ou dois dias até Santos a descer a Serra do Mar pelo tortuoso Caminho de Anchieta, na sacolejante diligência; depois, até o Rio de Janeiro, outras 24 ou mais horas, de vapor. Mal lhe chegavam as notícias da Corte e do mundo. Foi a mais tardia das províncias do Império a receber a imprensa. O Paulista, seu primeiro jornal, foi escrito à mão, "su- 
prida a falta de tipografia pelo uso de amanuenses, pagos por uma sociedade patriótica", explicava Antônio Mariano de Azevedo Marques, o Mestrinho, conhecido mestre de latim (daí o apelido), seu fundador e redator. Publicado em 1823, durou uns poucos meses. Agora, só $O$ Ypiranga, fundado em 1849, ainda sustentava a bandeira liberal naqueles tempos em que a conciliação amainara um pouco as acirradas lutas políticas; o Correio Paulistano, criado em 1854, órgão oficial do governo, que só em 1869 passaria para os liberais, por influência de Américo de Campos ${ }^{14}$, uma vez ou outra no mês dava Notícias da Barca que chegava ou partia de Santos; em 1865, o Diário de São Paulo, moralista e reacionário, iria servir aos jesuítas e religiosos. Em 1864, o Diabo Coxo merece destaque. Pequeno e de curta duração, mas um dos marcos mais importantes na história da imprensa paulista, o Diabo Coxo foi o primeiro jornal ilustrado e de caricaturas de São Paulo, graças à litografia e ao lápis de Ângelo Agostini, que contava então 21 anos apenas, e viria a ser, no Rio de Janeiro, o maior e mais combativo caricaturista do Segundo Império. Luís Gama cuidava da redação, auxiliado às vezes pelo jovem e empreendedor Américo de Campos. Além desses semanários e diários, proliferavam os pasquins candentes dos estudantes em desaforada verborragia libertária, temperada com sátiras mordazes e humor corrosivo, ao lado dos folhetins de jovens poetas sonhadores de açucarados versos românticos.

Poucos eventos, além do teatro, das missas e dos poucos bailes, conseguiam encher os domingos e dias santos do povoado, sacudindo-lhe um pouco o modorrento dia-a-dia, como um leve vento a the agitar a calmaria. Domingos de festas religiosas, com as devotas contritas acompanhando as procissões do Divino, da Semana Santa, do Corpus Christi, cobertas de mantilhas negras; dos salões provincianos nos casarões de burgueses abastados ou nobres interioranos, quando senhoras bem vestidas deslizavam seda e cores no balão dos seus vestidos longos, e sinhazinhas, de olhos buliçosos atrás dos leques, buscavam cativar o sinhozinho elegante; dos concorridos saraus da Marquesa de Santos; de um ou outro 
baile de mascarado em salão belamente ornado de festões, onde rodavam os pares ao som das walsas, quadrilhas, schottish ${ }^{15}$; domingos do teatro, incipiente ainda, nas poucas casas de espetáculos, cuja assistência, três lustros depois, ainda "era quase inteiramente de homens, poucas famílias pelos camarotes", observaria com estranheza Taunay, ao visitar São Paulo ${ }^{16}$. O velho barracão da Casa da Ópera, na praça São Gonçalo (praça João Mendes), há muito já fechara suas portas; a Sociedade Concórdia Paulistana exibia alguns espetáculos mensais. Mesmo assim, o teatro despertava partidos de espectadores entusiastas, que se encantavam com os dramalhões românticos, As Ruínas de Babilônia, O Peregrino Branco, O Sonho ou O Terrivel Fim do Usurpador, A Familia Morel (extraídos dos Mistérios de Paris, de Eugène Sue) ${ }^{17}$. O São José, ao lado do Colégio dos Jesuítas, só seria inaugurado em 1864; nele, a atriz Júlia comoveria até às lágrimas o seleto público, encarnando a infortunada Margarida da Dama das Camélias; e se apresentariam os irmãos Lopes, de monumentais narizes, em comédias hilariantes; e o Vasques, "o rei das scenas comicas".

A música e o canto também não ascendiam além das modinhas e loas religiosas, uns poucos instrumentos animavam as festas populares e as plangentes serenatas. Mesmo estas já não eram tão comuns, como revela crônica de 1860: "São Paulo outrora tão famosa pelas suas serenatas; ainda as vezes recorda esses belos tempos - e haverá nada mais encantador que em uma linda noute de luar uma serenata?... o silêncio da noute quebrado pela doce harmonia de uma flauta?"'18

Apesar de tudo, São Paulo era uma aldeia grande. E começava a mudar. Nessa década, já o café estendia sua manta penteada a pente-fino pelos campos férteis da terra roxa, o transporte em lombo do burro agonizava, a estrada de ferro começava a lançar os trilhos nas lombadas da Serra do Mar abaixo para encontrar o porto de Santos. Com os prenúncios de progresso, as exigências culturais também começavam a crescer.

Ao raiar de 1861, São Paulo passou a contar com dois professores de música, ambos moços e talentosos: Emílio do Lago e 


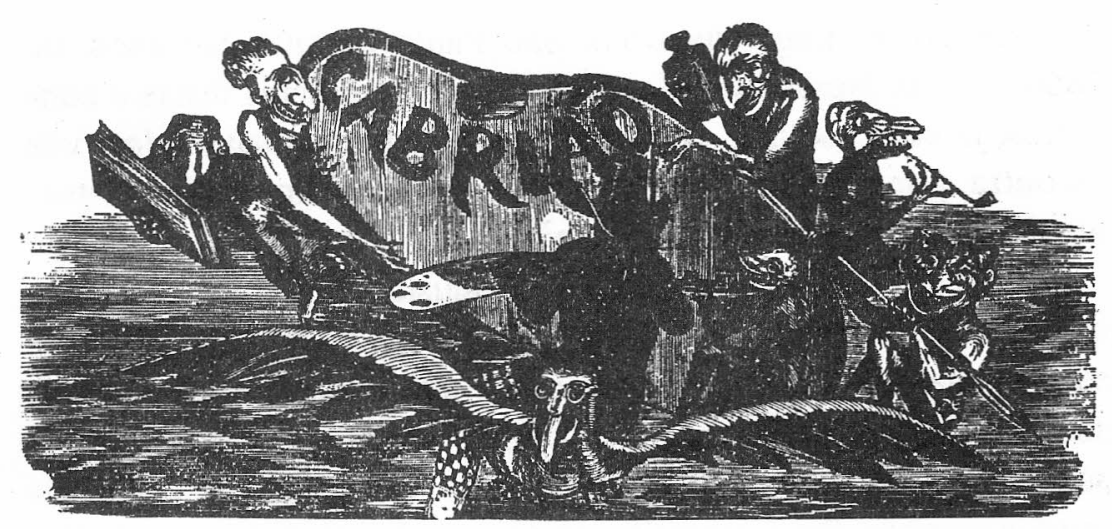

\begin{tabular}{|c|c|c|}
\hline 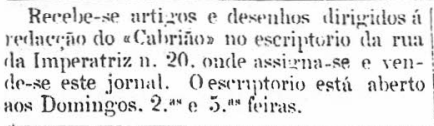 & 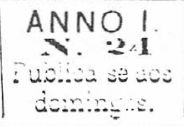 & 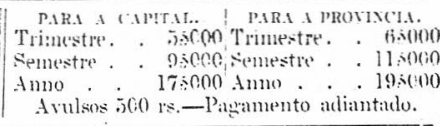 \\
\hline
\end{tabular}

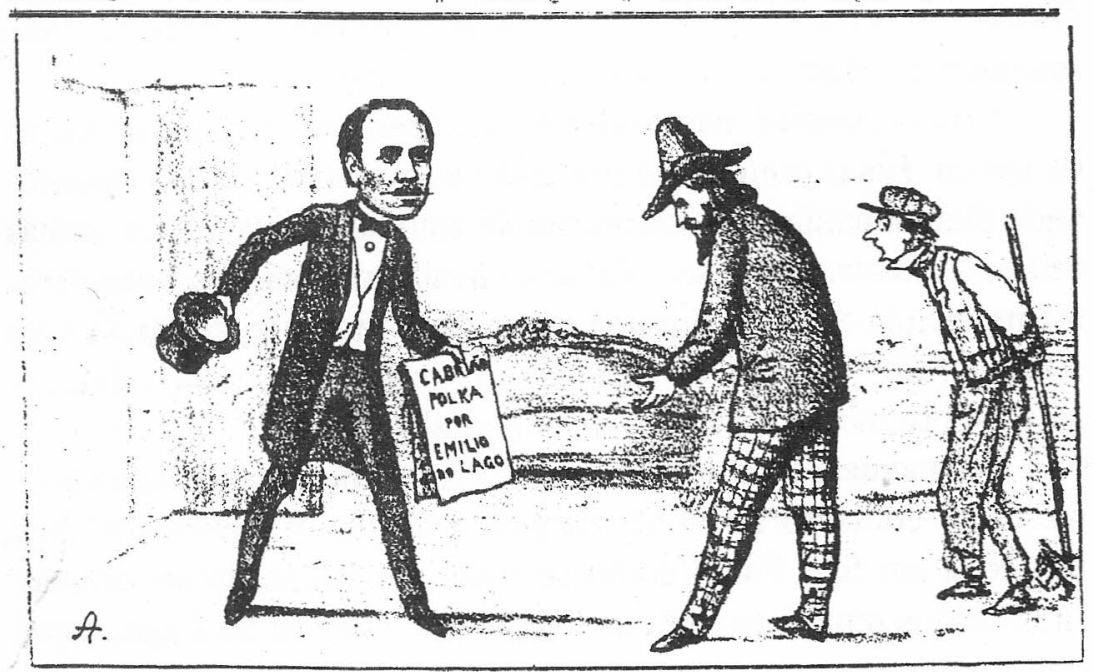

O Compositor Emilio do Lago entrega a "polka eleganten Cabriāo ao seu amigo Ângelo Agostini, aqui na autocaricatura e nas vestes do Cabrão figura-símbolo do jornal de mesmo nome (Cfr. jornal Cabrião, $n^{\circ} 24,17$ mar 1866 , pág. $1(10 \times 16 \mathrm{~cm})$ 
Gabriel Giraudon. "Um brasileiro, vivo, espontâneo e imaturo. O outro nascera em França e trazia consigo forte lastro de cultura e civilização"19.

Emílio do Lago viveu em São Paulo durante dez anos, de 1860 a 1870. Nesse período, participou de inúmeras festas e concertos, já como solista, já na posição de acompanhante. Uma vez ou outra, por necessidade de conjunto, tocou violino. O seu instrumento de eleição, porém, o piano ${ }^{20}$.

"Filho da província, aprendendo música - na roça, por assim dizer - sem outro mestre que seu próprio pai e seus irmãos, quase sem escolas, sem modelos conquistou muito assim mesmo. Sabe as regras de harmonia, é compositor, e tem uma destreza espantosa sobre o teclado. Sua execução rápida, atropelada às vezes, vigorosa sempre, faz lembrar Liszt. Como ele tem belezas, admira, também tem defeitos. Com os dedos que tem o Snr. Emílio, com as propensões artísticas de que é dotado, um mestre que andasse em dia com os progressos da arte tornava-o pianista consumado. Pelo seu talento, é digno de um conservatório de Paris". ${ }^{21}$

Como pianista, não poderia seu repertório escapar ao gosto da época. Eis o prato forte preferido pela inculta, porém, apaixonada platéia paulistana, composta de estudantes, caixeiros, sinhás dengosas, matronas desconfiadas e cavalheiros ociosos. Mais raramente incluía ele no programa peças de Gottschalk, como Savana e Bamboula ${ }^{22}$. Mas já acrescentava fantasias e caprichos de concerto sobre motivos de óperas, em geral italianas.

Foi naquele mesmo ano de 1862 que, antecedendo apenas de meses ao concerto de Mme. Raquel, a família de Emílio do Lago apareceu em São Paulo como se fosse um bando de andorinhias. Eram todos musicistas: Manuel Prudêncio Correia do Lago, o pai, compositor e maestro; Francisca Romoalda Correia do Lago, soprano e pianista; Francisca Luiza Correia do Lago, sobrinha de Emílio, pianista; Cherubina Maria do Céu Correia do Lago; Ambrosina Maria Correia do Lago, irmã; e José Juvita Correia do Lago ${ }^{23}$.

É possível que haja a família Lago residido algum tempo em Campinas, porque foi lá que o jovem Emílio se afeiçoou a Carlos 
Gomes. Ademais, narra a tradição, como lembra İtala, filha do maestro, que Ambrosina Maria, irmã de Emílio, tomou-se de amores pelo Tonico, que, correspondendo aos seus acenos, teria dedicado a modinha Quem Sabe?!... não a Emílio, como está na partitura, mas a ela ${ }^{24}$.

O primeiro concerto realizou-se num sábado, 31 de maio de 1862, no salão do Hotel das Quatro Nações, Pátio do Colégio. Extenso programa, com números de piano por Emílio do Lago e D. Francisca Luiza, e de canto pela soprano D. Francisca Romoalda. O trecho difícil deve ter sido a "Ária e Coro" da ópera Nabucodonosor, de Verdi, cantada por toda a família. Ademais, tocou a orquestra duas peças de Manuel Prudêncio Correia do Lago, uma quadrilha e a grande valsa Os Estudantes em Férias, dedicada ao corpo acadêmico.

O segundo concerto foi efetuado em 29 de junho de 1862, no salão da Concórdia Paulistana, onde se aglomeraram mais de trezentas pessoas. A novidade do programa, todo ele recheado de ópera, foi a apresentação, pela primeira vez na cidade, de um trecho da recentíssima ópera de Carlos Gomes, A Noite no Castelo, cantada em coro pela família Lago, com acompanhamento de violino (Emílio do Lago), clarineta (Henrique Luiz Levy), rabecão (José Juvita do Lago) e flauta. Aplausos, flores e versos recitados por acadêmicos coroaram a festa ${ }^{25}$.

Mais tarde, em 1863, a loja Henrique Luiz Levy \& Emílio Corrêa do Lago, como outras poucas que já importavam músicas para flauta e piano, recebia da Corte uma grande remessa de 1.800 exemplares de composições, que andou anunciando e vendendo. Para contentar os clientes, o próprio Emílio tocava ao piano as peças, que eram "dos autores de maior nota no mundo musical tais como Thalberg, Liszt, Fumagalli, Prudent, Chopin, Ravina, Gottschalk"26.

Em 1866, Emílio do Lago esteve à testa da orquestrinha do Teatro São José, regendo-a na indefectível ouverture ${ }^{27}$ dos espetáculos dramáticos. Já a esse tempo eram conhecidas e tocadas na cidade várias composições de sua autoria. A primeira do seu acer- 
vo, Último Adeus do Amor, impressa logo depois em Paris, impõese à consideração dos estudiosos pela sua "bonita linha e importância musical, segundo Mário de Andrade, com efeito, é bastante característica na mixórdia de cultura e populismo que ia no movimento modinheiro de salão, no Segundo Império. Tudo nesta obra deliciosa é briga entre pretensão, tradições cultas e espontaneidade popular ${ }^{28}$ ". Outra composição, O Canto da Coruja, espalhouse pelo país e mereceu nada menos que três caricaturas de Ângelo Agostini no jornal Diabo Coxo ${ }^{29}$. Em 1866, Agostini mostra a cena a Emílio que lhe entrega a partitura de Cabrião, "graciosa polca elegante", dedicada também ao Cabrião $0^{30}$, que era ao mesmo tempo jornal, a personagem-símbolo do jornal e ele próprio, Agostini, em autocaricaturas nas vestes da personagem.

O jovem Emílio conquistou amizade dos jovens que, por incrível coincidência, formavam, na mesma época, um grupo notável de futuras personalidades importantes de nossa história na política, nas artes, na imprensa: Américo de Campos, Carlos Gomes, Ângelo Agostini, Rui Barbosa, Luís Gama, Sizenando e Joaquim Nabuco; um pouco antes Álvares de Azevedo, mais tarde Castro Alves (que também tem versos musicados por Emílio), Olavo Bilac e muitos outros. Talvez, na alegria folgazã de sua juventude, se irmanassem todos, ora em calorosas arengas idealistas, ora bebericando nas adegas, ora nefelibatas, embalados no haxixe, sonhando sonhos românticos, ora entoando apaixonadas serenatas em noites de bruma e garoa ou à luz da lua e dos bruxuleantes lampiões a querosene das pacatas ruelas de São Paulo de então.

Era mais ou menos esse o contexto social que ouviu Mme. Raquel.

Não se sabe se esta foi, de fato, sua primeira apresentação nos palcos paulistanos, mas outras se seguiram, como se registra, de 1862 a 1864, nos poucos números existentes do Correio Paulistano $^{31}$, o que revela que Mme. Raquel não esteve de passagem por São Paulo, mas aí residiu por alguns anos. Pode ser que tenha vindo com alguma companhia lírica, ainda que não haja nenhum registro nos números existentes dos jornais; o que se consta- 
ta é que, durante sua estada, não esteve vinculada a nenhuma delas, nem mesmo às pequenas Companhias Teatrais da cidade.

Seria então possível dizer, com muita certeza, tendo em vista os registros e anúncios dos jornais, os únicos documentos existentes, que Mme Raquel de Almeida foi a primeira cantora lírica a se apresentar na pequena São Paulo de então e a despertar-lhe o gosto pelo bel canto!

Não é, porém, o que dizem diversos autores, embora, sem estarem convictos do que afirmam, divirjam muito em datas e nomes.

Wanderley Pinho, por exemplo, garante: "Foi só por volta de 1875 que São Paulo conheceu pela primeira vez uma companhia lírica, da qual faziam parte a Cortezi, o Pezzoli, Mirandola, Pons, Limberti, Lelini ${ }^{22 "}$.

Para o redator de A Província de São Paulo, "parece que foi o tenor Ernesto Rossi quem abriu, bem mais tarde, a série dos milagres em São Paulo. À passagem de Rossi pelo palco paulista em agosto de 1879 opera-se uma revolução ${ }^{33}$. Só então, Ferrari, empresando uma companhia lírica, via completas as assinaturas para os concertos", concorda Wanderley Pinho, contradizendo o que havia afirmado antes ${ }^{34}$. "Agora as casas se enchiam para ver representar o grande trágico, a platéia aplaudia. Longe ia o triste tempo, quando Gottschalk ${ }^{35}$ estivera em São Paulo e vira o [teatro] São José quase vazio. (...) Mesmo assim, o gosto pela boa músi$\mathrm{ca}$, se veio forte, chegou tarde: o primeiro concerto vocal e instrumental em termos ocorreu ali em 1880", atesta por sua vez A. C. no Diário Popular ${ }^{36}$. "Fora um verdadeiro acontecimento que pôs em reboliço os antigos hábitos da população que até essa data muito pouco mais conhecia além das missas cantadas e da música de permanentes".

A. C. é certamente o pseudônimo sob o qual se ocultava Américo de Campos, proprietário do Diário Popular. Soa estranha então esta sua afirmação, pois, quando estudante, ele foi redator de jornais da época, contemporâneo, portanto, de Mme. Raquel, e não é nada impossível imaginar até que lhe tenha assistido ao concerto naquele domingo, 26 de novembro de 1862 ! 
Esquecimento? Falta de uma pesquisa mais atenta nos jornais da época? ou inexistência de dados e documentos? Infelizmente, a realidade deve ser esta, pouca coisa restou do nosso passado. Somente os jornais $O$ Futuro e o Correio Paulistano, nos poucos exemplares ainda existentes, trazem notícias de Mme. Raquel. Outras talvez tenham sido publicadas, algum artigo sobre suas qualidades e desempenho como cantora e atriz, mas tudo está irremediavelmente perdido.

Mas quem foi Mme. Raquel de Almeida?

Com sobrenome tão nosso, brasileiro, seria mesmo "filha da Itália", como registrou a imprensa? Teria sido realmente, como se afirma, uma prima donna de carreira tão brilhante pelos teatros da Europa? Por que, então, teria deixado os aplausos e os louros de um centro cultural tão desenvolvido para vir cantar numa pequena vila, quase deserta, esquecida nas matas do planalto paulista? E por que motivo, em vez de São Paulo, não escolhera o Rio de Janeiro, quando a Corte já era um centro cultural bem desenvolvido de animados saraus e concorridos teatros, em que se apreciavam imensamente as óperas e recitais apresentados por grandes companhias líricas e artistas de renome? Que músicas teria cantado? Quando teria chegado ao Brasil? E em São Paulo? Viera só ou encabeçava o elenco de alguma grande companhia lírica? Deixara a companhia para residir em São Paulo? Por que?

Tudo é muito instigante. A pesquisa apaixona. Quase sempre um problema resolvido nos leva a mais um ou a muitos outros. Os poucos documentos que ainda existem em nossos arquivos e bbliotecas podem desanimar o pesquisador ou, pelo contrário, incentiválo a enfrentar mais decididamente o desafio.

Não satisfeitos, porém, seria um prazer dividir este desejo de descobrir mais com o leitor cotucado pela mesma curiosidade, convidando-o a palmilhar o caminho de Mme. Raquel, perseguindolhe, de volta, os mesmos passos.

A viagem é longa e imprevisível. É um dia inteiro, ou mais, na penosa diligência do sr. Avellar rumo a Santos, em ziguezagues e 
solavancos descendo a Serra do Mar, ainda que rode por sobre o macadame ${ }^{37} \cdot$ recém-colocado na estrada.

Santos, porém, traz-nos a primeira decepção. Nada foi encontrado, não se conservou nenhum registro, nenhum livro de bordo dos vapores, fragatas e das muitas outras embarcações que lá atracavam. Mais proveitoso, dizem, seria ir ao Rio de Janeiro, onde é mais provável encontrar melhores informações nas folhas diárias da Corte, como o Jornal do Comércio, por exemplo, que tem uma seção inteira sobre o Movimento do Porto; ou no Arquivo Nacional, onde se guardam os registros de todos os estrangeiros chegados ao Brasil.

O vapor Santa Maria, do Comandante Joaquim da Silva Ferreira, partiria de Santos para o Rio nos dias 5, 15 e 25 de dezembro de 1862 , às quatro da tarde, como anuncia o Correio Paulistano $^{38}$. Também o vapor Pirahy tinha linha regular de cabotagem entre as duas cidades. Não era uma viagem tranqüila nem muito agradável, eram mais de 24 horas no balanço do mar, passageiros mal acomodados entre a correria da pequena tripulação de dez a onze homens, da carga de "vários generos" e, quase sempre, dos "escravos a entregar, todos creoulos".

No entanto, a estada no Rio também não traz maiores proveitos. As primeiras pesquisas nada revelam. Assim é que as mesmas perguntas suscitadas pelos jornais paulistas continuam a remoer 0 cérebro.

Só muito mais tarde, doze anos depois, em 28 de agosto de 1874, a revista ilustrada Vida Fluminense dava esta triste nota:

"Após prolongada e dolorosíssima enfermidade, falleceu na Itália a Exma. Sra. D. Rachel Agostini de Almeida, esposa do nosso amigo o Sr. A. P. Marques de Almeida, proprietário desta folha, e a mãe do sr. Angelo Agostini, co-proprietário do Mosquito. A Sra. D. Rachel, dedicando à arte religioso culto, foi uma virtuose muito distinta". 39

Apesar de infausto, o noticiário esclareceu mais alguns pontos: 
- a Sra. Rachel Agostini de Almeida, a virtuose "dedicada à arte", é a mesma prima dona, Mme. Rachel de Almeida, que encantara os paulistanos com o "trinar de sua voz candente e sonora";

- o nome "Agostini" confirma sua origem italiana e o "Almeida" the veio do casamento com o Sr. A. P., ou António Pedro Marques de Almeida;

- e o muito importante, Raquel era mãe de Ângelo Agostini, o famoso e cáustico caricaturista do Império.

Vê-se então que ambos estavam entre os que propiciaram o desabrochar do movimento cultural de São Paulo, o filho ao the abrir o mundo encantado da imagem, a mãe a despertá-lo para os maviosos sons do bel canto.

As informações, no entanto, iriam se completar somente depois de mais doze anos, em 1886, com outra notícia publicada na Revista Illustrada, de Ângelo Agostini:

"Temos o desgosto de registrar, hoje, n'estas paginas, o fallecimento de um antigo e leal companheiro de imprensa, muito conhecido jornalista e geralmente extimado pela lhanesa do seu trato: Antonio de Almeida. fundou alguns jornaes illustrados, que se tornaram celebres, e aonde collaboraram artistas de grande merito, entre elles, Borgamainerio. A Vida Fluminense e o Figaro, não foram esquecidas pelo publico, que se recorda ainda de algumas das suas bellas paginas illustradas". ${ }^{40}$

António de Almeida, como era conhecido o "antigo e leal companheiro de imprensa", era o padrasto de Ângelo Agostini, que também trabalhou nos jornais que fundou. Werneck Sodré já havia anunciado esse parentesco sem apresentar, porém, nenhum documento: "Pela mão do padrasto, António Pedro Marques de Almeida, [Ângelo Agostini] percorreu a imprensa paulista, em que o lápis litográfico como arma de combate era desconhecido"4l.

Em pesquisas posteriores, encontramos no Jornal do Comércio:

"Antonio Pedro Marques de Andrade [sic] (ausente), Angelo Agostini e sua família, Joaquina Palha de Faria Lacerda e seus filhos, rogão pessoas de sua amizade e mui pranteada esposa, mãi e cunhada D. Rachel Agostini de Almeida, fallecida na Itália em 14 


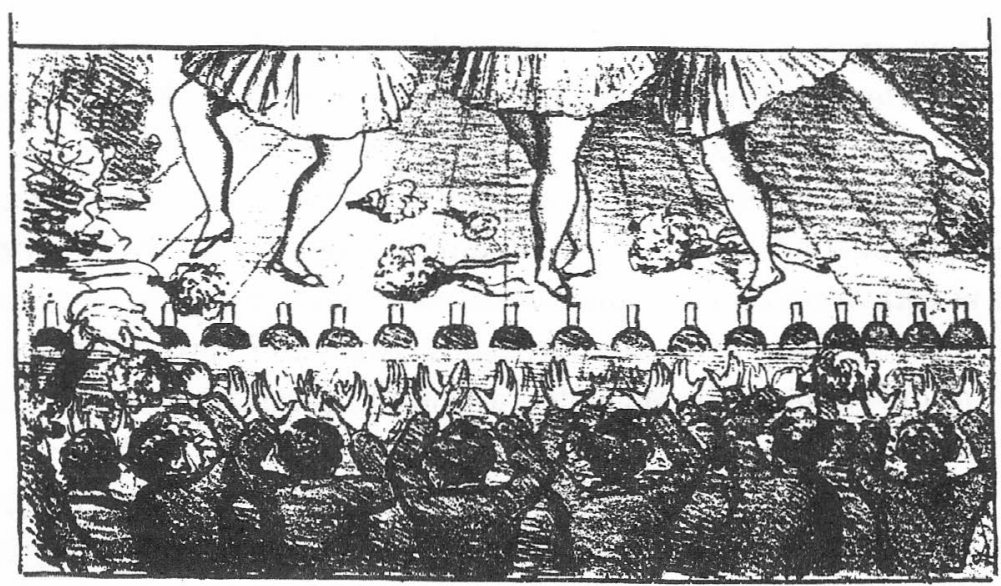

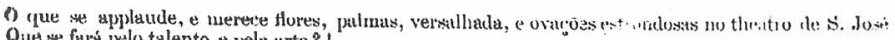
Que sará palo talento o pela urte?!...

Ovaçăo às bailarinas da Cia. de Balé que se apresentou no Teatro Săo José (jornal Cabriăo, $n^{\circ} 32$, 12 mai $1867,9 \times 16 \mathrm{~cm})$

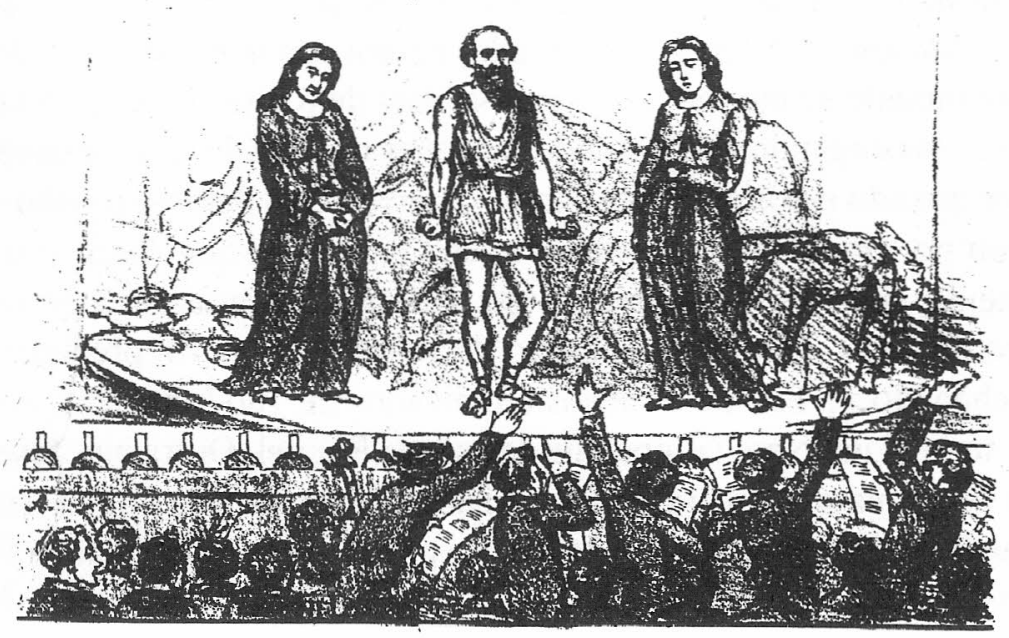

Companhia Ireller em santos.

Ferão tantns ns poesins tos morinhos de S. Paulo, que chegaräo a amolar o publicu. o propr:o Keller

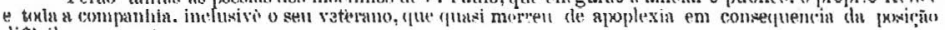
difficil en que estara.

E clumu-spe a istı - umu ovarğo !!!! 
de junho deste ano, o favor e caridade de assistir a missa que em sufragio de sua alma será rezada às $8 \frac{1}{2}$, Igreja de S. Francisco de Paula, hoje, segunda feira, 31 do corrente $[1874]^{42}$.

Os detalhes desta notícia ajudam a completar o quadro: a data exata da morte de Raquel, 14 de julho de 1874; Ângelo Agostini, que já estava no Rio, família constituída, filhos e esposa, esta nobre senhora, filha de conde português. António Pedro, "ausente", estaria provavelmente, na Itália, assistindo a esposa em seus últimos momentos.

Os necrológios, no entanto, se de um lado respondem a algumas indagações que vinham sendo postas, de outro, fecham a possibilidade de encontrar mais dados sobre a vida de Raquel. Ao deixar de indicar a cidade da Itália em que faleceu, impossibilitam todos os esforços para saber o lugar e a data de nascimento, onde viveu, a família, os descendentes. Todavia, aguçam ainda mais a curiosidade e forçam pesquisas posteriores.

Ângelo Agostini há muito já se encontrava no Rio, trabalhando, nesta época, como caricaturista em seu próprio jornal ilustrado, O Mosquito. Não foi encontrada, porém, nenhuma informação sobre quando se mudou. O mesmo se diga de Raquel e de António Pedro; mas ligando e amarrando informes daqui e de lá, é possível saber quando e por quê toda a família deixou São Paulo e passou a residir no Rio de Janeiro. Uma primeira hipótese é que António de Almeida, para ter fundado a revista Vida Fluminense em 3 de janeiro de 1868 , data da publicação do primeiro número, precisaria ter chegado ao Rio pelo menos em meados de 1867, quando, então, teria viajado em companhia da esposa Raquel. Outra hipótese, que confirma a primeira, é que teriam viajado, os três juntos em setembro desse mesmo ano de 1867 e que Ângelo, após a violenta "devassa" no seu Cabrião, escapara às pressas das enfurecidas vítimas de suas caricaturas, mal tendo tempo de ilustrar-lhe o $\mathrm{n}^{\circ} 50$, de 22 de setembro de $1867^{43}$, tanto que o número seguinte do jornal já trazia os traços e assinatura de outro desenhista, provavelmente Nicoláo Hascar ${ }^{44}$. E foi o último! O Cabrião encerrou definitivamente sua publicação na semana seguinte. 
Mas, já lá estava ele nas páginas do Arlequim logo no mês seguinte desse mesmo ano, azucrinando de novo a todos com suas caricaturas apimentadas ${ }^{45}$.

A pergunta seguinte, porém, de quando teriam chegado ao Brasil e em São Paulo, e mais as outras, ainda estão de pé. Até hoje ninguém cuidou de saber sobre Raquel e António Pedro, apenas sobre Ângelo Agostini, por sua efetiva e destacada participação na vida política e social brasileira. Mas nem quando tratam apenas de Ângelo os autores são unânimes quanto à data de sua chegada. $\mathrm{O}$ ano de 1859 é o mais comumente aceito. Ele teria então 16 anos apenas. Por ser tão jovem, pode-se presumir que tivesse vindo em companhia da mãe. O que é certo é que nenhum historiador fundamenta suas afirmações, ou porque nenhum documento foi encontrado, ou porque não consultaram duas fontes fundamentais disponíveis ainda hoje no Rio: o Registro dos Estrangeiros, que pode ser encontrado no Arquivo Nacional, e o Movimento do Porto, coluna diária do Jornal do Comércio (desde 1827), cujo microfilme está à disposição na Biblioteca Nacional. Aquele guarda o nome de todos os estrangeiros registrados no livro de bordo dos navios que atracavam no porto do Rio de Janeiro; o Movimento do Porto, preciosa seção do jornal, traz a transcrição daqueles mesmos registros.

A leitura dessa seção do jornal é interessante ou ao menos curiosa. Nela são registrados os portos de partida ou de destino, a duração da viagem em dias, o tipo, nome e tonelagem da embarcação, o nome do capitão, a tripulação e, o mais importante para o pesquisador, o nome dos passageiros agrupados pela nacionalidade indicada no passaporte, com exceção dos brasileiros que eram mencionados em primeiro lugar; depois os portugueses e, em seguida, os das demais nações.

É um celeiro rico de inúmeras outras informações, além daquelas que interessam mais de perto a esta pesquisa. Sabe-se, por exemplo, que a década de 50 foi de intensa imigração européia, principalmenre de portugueses e alemães, que aqui chegavam em grandes grupos. Não raro, dos grupos menciona-se apenas a nacionalidade, sem discriminar-lhes os nomes, talvez, por já estarem, 
antes de empreender viagem, na lista das companhias que os contratavam na origem para aqui trabalharem na lavoura, como estas mencionadas no jornal: a Associação Central de Colonização, Companhia União e Indústria e Companhia do Mucuri ${ }^{46}$.

Certamente nossos heróis não estavam entre os anônimos componentes desses grupos. Mas, em dado momento, entre esses surge um registro preocupante:

- 13 de maio de 1859: de MARSELHA por Port. Vendres 63 dias do último [porto], barca francesa Emilie, 232 ton., M.I.H.A. Cysanther, equip. 10; carga, sal e vinho a Decorted e Pradez; passageiros 144 italianos artistas.

- De BORDEAUX, 52 dias, ... pass. 1 italiano, 20 franceses, todos artistas ${ }^{47}$.

Estariam eles entre aqueles artistas italianos ou franceses? É possível. Se estavam, esvai-se toda a esperança de encontrar qualquer notícia sobre sua chegada. Mesmo a hipótese de terem entrado antes pelo porto de Santos, numa daquelas embarcações que vieram da Europa, aportando antes em Buenos Aires ou Montevidéu, não nos daria a menor chance de encontrá-los, porque em Santos não se conservou nenhum registro de passageiros como no Rio. Tudo se perdeu.

E António de Almeida, o padrasto? Seria brasileiro? Se paulista, explicaria por que se estabeleceram antes em São Paulo e não no Rio. Raquel o teria conhecido aqui ou na Europa? Onde teriam contraído matrimônio? As perguntas proliferam na aridez das respostas.

Talvez mais uma revisão meticulosa na seção do Movimento do Porto do Jornal do Comércio ajudasse. No domingo, 9 de setembro de 1860, anunciava-se que zarparia uma embarcação da linha de cabotagem do Rio para a cidade de:

SANTOS. Vapor Pirahy, 109 toneladas, M. Joaquim da Silva Ferreira, equip. 16; carga varios generos; passageiros os Franceses... [seguem-se nomes], o Italiano...; o Inglês...; e os portugueses Antonio Pedro Marques de Almeida, Joaquim José da Cruz Torrisqueira, Manoel da Silva, e 16 escravos a entregar. ${ }^{48}$ 
Maravilha! Alguma coisa foi encontrada! Sabe-se agora que António Pedro era português e a data exata em que se dirigira para Santos. Certamente, logo em seguida, deve ter subido a serra, de diligência, rumo a São Paulo!

Nesta mesma notícia há outros dados que poderão servir à história: a cabotagem regular entre os dois portos do Rio e Santos era feita pelos dois vapores: Santa Maria e Piraí, comandados ou de propriedade do mesmo sr. Joaquim da Silva Ferreira.

Persistir é sempre bom! Continuando as "escavações", apareceu na mesma coluna do Movimento do Porto do Jornal do Comércio, no sábado, 17 de novembro de 1860 (mais de dois meses depois!), o mesmo vapor, o mesmo comandante, a mesma tripulação, dirigindo-se ao mesmo destino:

SANTOS - Vapor Pirahy, 100 tons.; M. Joaquim da Silva Ferreira; equip. 17; carga varios generos; passageiros Manoel Luiz Ferreira, Antonio Luiz Ferreira Moura, Manoel Pereira do Amaral, Joaquim Rodrigues Junior, os Francezes Romain Bonhomme, Antoine François Poullet et Louis Bourgeois; a portugueza Rachel Agostini de Almeida; e 7 escravos a entregar ${ }^{49}$.

Encontramos Raquel! Finalmente!

A indicação de nacionalidade portuguesa é aquela registrada no passaporte e revela que Raquel e António, antes de partirem com destino ao Brasil, já teriam se casado, provavelmente em Portugal mesmo, o que explicaria, em parte, que Raquel, para viver ao lado do marido, optara por abandonar sua carreira de conceituada cantora lírica na Europa, mesmo tendo que enfrentar viagens tão duras e viver, ignota, numa pequena aldeia escondida nas selvas do planalto. Se foi encontrar-se com o marido somente dois meses, depois certamente foi para lhe dar tempo de encaminhar os afazeres e negócios de preparar um lugar onde se estabelecerem. Confirma-se também, em parte, aquela informação de Werneck Sodré, mencionada pouco antes sobre Ângelo Agostini.

Estranhamente, porém, sobre a chegada dos três no Rio, não foi encontrado nada, absolutamente nada, ainda que revirássemos o Movimento do Porto desde 1852 a 1862. Estariam mesmo, como 
supúnhamos, entre aqueles anônimos artistas italianos ou franceses chegados um ano antes, a 14 de maio de 1859 ?

Impossível saber. A documentação existente é apenas essa. É tudo! e só!

Continuam ainda sem resposta todas aquelas outras questões colocadas antes e mais outras que surgem agora, a cada pequena notícia que se encontra.

Quem foi mesmo Raquel Agostini de Almeida? Quando exatamente teria chegado ao Brasil? $\mathrm{E}$ a mais instigante de todas as perguntas:

Por que teria ela abandonado as grandes platéias do mundo que arrebatou com o melífluo trinar de sua voz candente e sonora? ${ }^{50}$

Amor, talvez? Algum insucesso?

Teria sido mesmo uma grande cantora? O que cantava naquele domingo? Que músicas the formavam o repertório? Qual era o timbre de sua voz?

Aquela notícia da Vida Fluminense, dada assim pela metade, pouco pode ajudar ${ }^{51}$. Serve apenas como sugestão. Só com muito custo, paciência, tempo e, sobretudo, com muita sorte se poderiam encontrar mais notícias. Estas todavia já completam parte do quebra-cabeça.

Aproveitando uma estada em Milão, quando lá estivemos para apresentar no Salão Cartoomix, uma exposição das obras de Ângelo Agostini, especialmente as de histórias em quadrinhos (feitas há 130 anos!), poderíamos tentar avançar mais um passo na pesquisa. Fomos ao Teatro Alla Scala. A esperança era até de encontrar o retrato de Raquel entre os inúmeros de tantas daquelas prime donne do passado. Nada. Mas, para entusiasmar bastante, lá estava registrado entre os verbetes de um antigo dicionário da $\mathrm{Bi}$ blioteca:

"AGOSTINI, Rachele. - cantante (att. 1837-38)". ${ }^{52}$

$\mathrm{O}$ pequeno achado representa muito! Figurar num dicionário confirma que sua atuação por dois anos, ou talvez mais, no meio artístico daquela época áurea da ópera, teve significativo destaque. 
Rèsultado mais que animador! Na falta de outras notícias, a data precisa das apresentações de Raquel permitia levar a indagação aos jornais daqueles tempos. O La Moda, giornale dedicato al bel sesso, que se encontra na Biblioteca Comunale de Milão, consagra uma seção inteirinha ao movimento musical e operístico nos teatros da Europa e também de todo o mundo ${ }^{53}$. E foi exatamente lá que encontramos Raquel outra vez.! Entre "le Compagnie di canto, balli e dramatiche scrituratte per il prossimo Carnovale 1838-39"54, encabeçava o elenco do Teatro Nuovo, em Pésaro, cidade que, antes da unificação da Itália, formava os antigos Estados Pontifícios juntamente com Roma, Bolonha, Ferrara, Forli, Cesena, Ímola, Faenza, Fermo, Ancona, Perúgia, Ravena, Macerata, Fano e Spoleto:

PESARO. Prime donne: Sig. ${ }^{\text {a }}$ Agostini Rachele

Sig. ${ }^{a}$ Lang Paolina [ou contralto, registra-se alhures]

primo tenore assoluto: Sig. Giampietro Emilio primo basso assoluto: Sig. Bonafoux Orazio.

$\mathrm{E}$, recompensando ainda a insistente procura, o $\mathrm{n}^{\circ} 3$, de 10 de janeiro de 1839 , do mesmo jornal La Moda, trazia, na página 12, um urtigo crítico sobre seu desempenho na ópera Gemma di Vergy, de Donizetti, e o elogio intimamente tão esperado: " $L a$ prima donna Agostini Rachele colla bella e agile sua voce si fece applaudire" "5s.

Em 15 de dezembro de 1995, o sr. dr. Alberico Miniucchi, diretor do Servizio Teatri e Attività di Spettacolo da Prefeitura de Pésaro, gentil e solicitamente nos enviou a carta do historiador local, professor Gilberto Calcagnini, escrita em 5 de dezembro de 1995, em que, muito atencioso também, dava-nos outros informes preciosos extraídos do livro Memórias do Teatro de Pésaro, que transcrevemos ${ }^{56}$, como complemento às notas do jornal La Moda, apresentadas acima: 


\section{9 - Carnevale - Impresa Micheletti. \\ - GEMMA DI VERGY - del maestro Pacini (?) \\ - GIULIETTA E ROMEO - del maestro Vaccai (57) \\ Artisti - Prima donna: Rachele Agostini \\ - Contralto: Pia Lanck \\ - Tenore: Emilio Giampietro \\ - Baritono: Bonnfox \\ - Basso: Ponti. ${ }^{57}$}

E o professor Calcagnini acrescenta ainda algumas gustose anotações sobre o abuso de ingressos alla portoghese $e^{58}$ por parte dos empregados ou adidos municipais, isentos, segundo um velho costume, de adquiri-los; e sobre a proibição da indesejável e incômoda gritaria, nos intervalos, dos vendedores ambulantes de cialde e biscotti, e di ceci, sementi e fave ${ }^{59}$, cujo consumo então era incrível; e sobre o nome do Teatro di Pesaro que, em 1839, chamava-se ainda Teatro Nuovo e não Teatro Rossini, como fora intitulado "por decreto municipal e dos senhores condôminos" em 1855 .

As Memórias do Teatro de Pésaro registram dois erros: a ópera Giulietta e Romeo é do Maestro Vaccari, "o cisne catanese"; Gemma di Vergy foi composta por Donizetti (Domenico Gaetano Maria Donizetti), em 1834; tem apenas dois atos e libreto de E. Bidera, baseado no romance Charles VI, de Dumas. Outro númer, do La Moda traz uma síntese do argumento dessa ópera ${ }^{60}$. Foi apr ssentada pela primeira vez no Teatro Alla Scala, em Milão, em 26 de outubro de 1834, com a interpretação de La Malibran, a mais festejada diva da época ${ }^{61}$. La Moda registra ainda várias outras apresentações de Gemma di Vergy, naquele mesmo ano de 1839, em diversos teatros da Itália e com as mais famosas vozes de então: Taccani, "La madamigella" Schoberlechun, Tadolini, Lalaude, Hungher, Strepponi ${ }^{62}$.

É uma satisfação imensa saber que Raquel, mesmo não sendo uma Malibran, estava entre as mais conceituadas cantoras líricas da época. O que não deixa de ser uma consagração. 


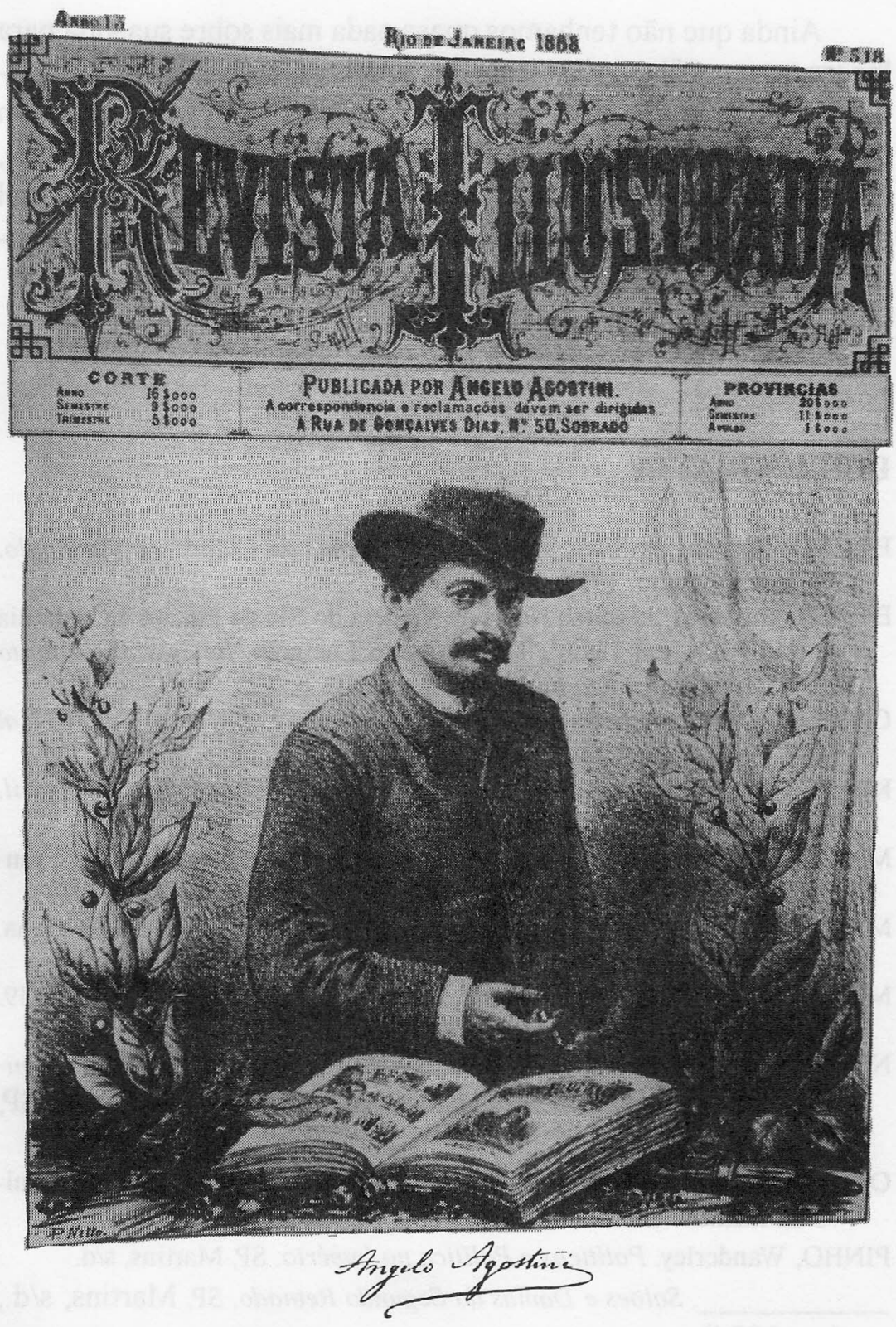

Ângelo Agostini (Vercelli, 1843-Rio, 1910), filho de Raquel Agostini. O mais importante caricaturista do Segundo Império nos traços do seu discípulo Pereira Netto (Cfr. Revista lllustrada, Rio, $n^{\circ} 518,11$ out 1888 , pág. $1(31 \times 22 \mathrm{~cm})$ 
Ainda que não tenhamos quase nada mais sobre sua vida para lhe traçar o perfil e contar dos seus sucessos, e, sobretudo, responder à instigante pergunta sobre as recônditas razões que a tiraram do auge de sua glória para viver numa aldeia quase inacessível, encarapitada no planalto paulista, podemos afirmar que Raquel Agostini foi a primeira cantora lírica de São Paulo, e que a encantou com

la bella e agile sua voce.

\section{BIBLIOGRAFIA}

BRUNO, Hernani da Silva. História e Tradições da Cidade de São Paulo. RJ, José Olympio, 1953. $3 \mathrm{v}$.

BEYER, Gustavo. "Ligeiras Notas de Viagem do Rio de Janeiro à Capitania de São Paulo em 1813". Trad. Alberto Loefgren. Revista do Instituto histórico e Geográfico de São Paulo, v. XII, p. 275.

CINELLI, Carlo. Memorie Cronistoriche del Teatro di Pesaro dal 1637 al 1837. Pesaro, da Nobili, 1898.

KIDDER, Daniel P. Reminiscências de Viagem e Permanência no Brasil. Trad. Moacir N. Vasconcelos. SP, Martins, s/d.

MARTINS, Antônio Egídio. São Paulo Antigo (1554-1910), v. 1. SP, Francisco Alves, 1911; v. 2, SP, Tipografia do Diário Oficial, 1912.

MAWE, John. Viagem ao Interior do Brasil. Trad. Solena Benevides Viana. RJ, Zélio Valverde, 1944.

MENSÁRIO do Jornal do Comércio, tomos IV, V,VI, dez. 1938 e jan.abr. 39. Cartas de Taunay à família.

NOGUEIRA, J. L. de Almeida. Academia de São Paulo (Tradições e Reminiscências - Estudantes - Estudantões - Estudantadas), 9 séries. SP, 1907-1912.

OTAVIANO, futuro visconde de Ourém. Carta de Otaviano a Areia, no arquivo do Instituto Histórico Brasileiro.

PINHO, Wanderley. Politicos e Politica no Império. SP, Martins, s/d. . Saloes e Damas do Segundo Reinado. SP, Martins, s/d.,

(ca. 1934).

REVISTA da Semana, (?) nov. 1941.

REVISTA NOVA, $\mathrm{n}^{\circ}$ 1, mar. 1931. Carta de Ramalho Ortigão a Eduardo Prado. 
REZENDE, Carlos Penteado de. Tradições Musicais da Faculdade de Direito de São Paulo.

SADIE, Stanley, ed. The Grove Dictionary of Music and Musicians. London, Macmillan Publishers Ltd., 1980.

SAINT-HILAIRE, Auguste de. Viagem à Provincia de São Paulo. Trad. Rubens Borba de Morais. SP, Martins, 1940.

SODRÉ, Nélson Werneck. A História da Imprensa no Brasil. RJ, Civilização Brasileira, 1966.

SPIX, João Batista von \& MARTIUS, Carlos Frederico Philippe von. Viagem pelo Brasil. Trad. Lúcia Furquim Lahmeyer. RJ. Imprensa Nacional, 1938.

VAMPRÉ, Spencer. Memórias para a História da Academia de São Paulo. SP, Livraria Acadêmica, 1924.

ZALUAR, Augusto Emílio. Peregrinações pela Provincia de São Paulo (18601861). SP. Ed. Cultura, 1943.

\section{NOTAS}

1. Prima donna, na expressão italiana, é a primeira e principal cantora de uma ópera.

2. La Grange e Stoltz, celebradas cantoras líricas que, nas décadas de 185060 , encantavam as platéias do Rio de Janeiro dos tempos do Império. Cfr. Wanderley PINHO, Salões e Damas do Segundo Reinado, São Paulo, Martins, s.d. (circa 1934), p. 251-263. Sobre La Grange, ver p. 258, 261; sobre Stoltz, p. 252, 256,258 e retrato, por Sisson, no encarte entre as páginas 252-3.

Rosina Stoltz, filha de pobre família de Paris, cujo nome verdadeiro era Vittorine Noeb, alcançou grande sucesso logo ao debutar em 1837. Chegou ao Brasil em 16 de abril de 1852, integrando uma companhia lírica. Foi a mais festejada e cara das prime donne que por aqui passaram. Em 23 de agosto de 1852, sessenta e seis mulheres, quebrando o velho costume, apresentaram-se no palco e lhe doaram uma coroa com um laço de brilhantes tendo ao centro uma esmeralda. $\mathrm{Na}$ apresentação de despedida em seu benefício, além dos muitíssimos presentes, La Candiani, outra diva do bel canto, dirigiu-lhe comovida a palavra e lhe cingiu a fronte com a coroa triunfal, doada pela Viscondessa de Abranches, por ela mesma recamada de pedras preciosas. Cfr. Vincenzo CERNICCHIARO, Storia della Musica nel Brasile, Milano, Fratelli Riccioni, 1926, p. 190-191 nota 9, p. 192-193.

Anne-Caroline la Grange, parisiense, foi chamada de "a rainha da cena lírica fluminense". Cfr. CERNICCHIARO, op. cit., p. 223.

3. Cfr. O Futuro, n' $20,27 / 09 / 1862$, p. 3. 
4. Mme. Rachel de Almeida ou d'Almeida, como também grafavam na época. O tratamento cerimonioso de "Madame" era, no Brasil, dado às senhoras; para as cantoras líricas, os italianos usariam a forma La prima donna Signora Almeida, ou, simplesmente, La Almeida; se muito jovem, La Madamigela Almeida.

5. Ver Emílio do LAGO, p. 7.

6. Apud W. PINHO, op. cit., p. 90.

7. João Batista von SPIX e Carlos Frederico Philippe von MARTIUS, Viagem pelo Brasil, Rio de Janeiro, Imprensa Nacional, 1938.

8. Sainte-Hilaire. Viagem à Província de São Paulo, São Paulo, Martins, 1940 apud PINHO, op. cit., p. 70-71.

9. Daniel P. KIDDER, Reminiscência de Viagens e Permanência no Brasil, São Paulo, Martins, s.d., apud PINHO, op. cit., p. 73-75.

10. La Candiani foi uma das mais famosas cantoras líricas no Rio de Janeiro de 1845 a 1855. "Era de vê-la fazendo desmaiar estáticos seus partidários às plangentes notas da Casta Diva: era de atentar para os ouvidos fitos, os olhos imóveis, as mãos já prontas e trêmulas da ânsia pelos apluasos, e, ao espirar o derradeiro e flebil eco da divina nota, irromper o bravo, grito estridente repetido por mil bocas... o grupo que estacionava firme à porta da caixa do teatro, esperava a Candiani para aclamá-la mais uma vez em despedida, inúmeros carros descobertos, enorme cavalgata, bandos de cantores e os competentes coros, seguidos da orquestra inteira do teatro, foram a uma hora da noite em demanda do alcantilado píncaro da graciosa mole que se banhava então de esplêndido luar verberado de límpido e constelado céu: $\mathrm{E}$ foi lá! foi do cume do poético rochedo dominando o oceano e a cidade inteira que se ouviu, em solene instante e... dentre as auras puras da madrugada, sussurrando na silente floresta, erguer-se 0 gorjeio merencóreo e suave de Candiani, trilando adoravelmente a Casta Diva." Cfr. Roberto TAVARES in Provincia de S. Paulo, 5 de junho de 1881. Logo depois, nas décadas de 50-60, brilhavam as estrelas do bel canto, La Grange e La Stoltz. Os freqüentadores assíduos das óperas tomavam partido desta ou daquela e, freqüentemente, acirrados os ânimos, travavam autênticas batalhas em defesa das suas prime donne favoritas.

11. Álvares de AZEVEDO em cartas dirigidas à mãe, transcritas por Luiz Felipe Vieira Souto, in "Dois Românticos Brasileiros", Boletim da Revista do Instituto Histórico Brasileiro, apud PINHO, p. 76.

12. Augusto Emilio ZALUAR, Peregrinações pela Província de São Paulo.

13. Cfr. PINHO, op. cit., p. 75.

14. Américo de Campos (1838-1899), jornalista, estadista, foi embaixador em Nápoles e Washington, grande amigo de Ângelo Agostini. Foi redator do Diabo Coxo (1864-5) e depois foi, com Agostini e Manuel Reis, proprietário do Cabrião, jornal ilustrado e de caricaturas (1866-7). Em 
1891 viria a ser também o fundador e maior acionista da primeira e autêntica empresa jornalística em moldes modernos e do jornal A Provincia de São Paulo. Com o advento da República, as províncias passaram a se chamar estados e o jornal também mudou o título para O Estado de São Paulo.

15. Correio Paulistano, $\mathrm{n}^{\circ} 1.193,8$ abr. 1860, p. 4.

16. Cartas de Alfredo E. TAUNAY à família, in mensário do Jornal do Comércio, tomos IV, V e VI, dez. 1938. Cfr. PINHO, op. cit., p. 85.

17. SODRÉ, História da Imprensa no Brasil, SP, Brasiliense, 1966, p. 215; e Almeida NOGUEIRA, Academia em São Paulo (Tradições e Reminiscências - Estudantes - Estudantões - Estudantadas), nove séries, sétima série, p. 109.

18. Correio Paulistano, $\mathrm{n}^{\circ} 1.126,13$ jan. $1860, \mathrm{p} .1$.

19. Carlos Penteado de REZENDE, Tradições Musicais da Faculdade de Direito de São Paulo, p. 121.

20. IDEM, ibidem, p. 123.

21. Francisco Antônio da LUZ, in Correio Paulsitano, 13 nov. 1860.

22. Gottschalk, Ascher, Schulhoff, Goria, compositores de polcas e schottisch bem conhecidos então. Cfr. REZENDE, op. cit., p. 122.

23. IDEM, ibidem, p. 123-4.

24. İtala Gomes Vaz de CARVALHO, Vida de Carlos Gomes, $2^{\mathrm{a}}$ ed., p. 61 e ss., apud REZENDE, op. cit., p. 122. Quem Sabe?!... é mais conhecida pelo verso inicial,: "Tão longe de mim distante..."

25. REZENDE, op. cit., p. 123-4.

26. REZENDE, op. cit., p. 125 e Correio Paulistano, $n^{\circ} 1.132,19$ jan. 1860, p. 4.

27. Correio Paulistano, $\mathrm{n}^{\circ} 1.141$, p. 4.

28. Mário de ANDRADE, Modinhas Imperiais, p. 15 e ss.

29. Diabo Coxo, $1^{\mathrm{a}}$ série, $\mathrm{n}^{\circ} 5,30$ out. 1864 , p. 5 , fig. $2(11 \times 17 \mathrm{~cm}) ; \mathrm{n}^{\circ} 11,11$

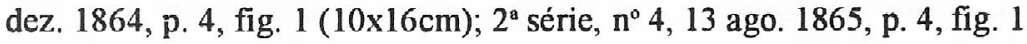
$(11 \times 17 \mathrm{~cm})$.

30. Cabrião, $\mathrm{n}^{\circ} 24,17$ mar. 1866, p. 185, 187.

31. Notícias ou textos sobre Mme. Raquel no Correio Paulistano (dadas as fal has existentes na coleção do jornal, não temos certeza se foram seis os concertos dados por Mme. Raquel): $\underline{1}$ - concerto? 1862 : elogiando sua apresentação em setembro: 5 out. 62,14 out. 62,17 out. 62,21 out. $62 ; \underline{2}^{\circ}$ concerto? Houve então solicitação de um novo concerto que afinal foi transferido: 23 out. 62,25 out. 62,26 out. $62 ; \underline{3}$ - concerto? 1863 : 14 jun. 63,16 jun. 63,17 jun. 63,18 jun. 63,19 jun. 63,5 ago 63,7 ago. 63,8 ago 63 ; $\underline{0}^{\circ}$ concerto? 4 out. 63,29 nov. 63 ; 5 concerto? $1864: 30$ mar. 64 , 31 mar. $64,1^{\circ}$ abr. 64,2 abr. 64; 60 concerto? 17 nov. 64,24 nov. 64,26 nov. 64 (apresentação) e 29 nov. 64. O jornal Diabo Coxo, em 26 nov. 64, $1^{\mathrm{a}}$ série, $\mathrm{n}^{\circ} 8, \mathrm{sd}$, p. 8 , fig. $2(12 \times 18 \mathrm{~cm})$, também publicou o anúncio desse 
concerto a ser "dado no sábado, 26 nov. 1864, por Mme. Rachel D'Almeida", em desenho de Ângelo Agostini.

32. PINHO, op. cit.

33. A Província de São Paulo, 17 ago. 1879.

34. PINHO, op. cit., p. 89-91. Ver também capítulo "Companhias Líricas e Grandes Cantores", p. 76-79.

35. Gottschalk, notável pianista em turnê pelo Brasil. Ver retrato em PINHO, $o p$. cit., em encarte entre as páginas 252-3.

36. Diário Popular, 22 maio 1885.

37. Processo de construção de estradas pela compactação de camadas de pedras britadas e saibro, recentemente inventado então por John L. MacAdam, de que se originou também o nome.

38. Correio Paulistano, $\mathrm{n}^{\circ} 1.870,1^{\circ}$ ago. 1862 , p. 3.

39. Vida Fluminense, $\mathrm{n}^{0} 348,28$ ago. 1874, p. 2.

40. Revista Illustrada, $\mathrm{n}^{\circ} 433,31$ mai.1886, p. 2.

41. Nélson Werneck SODRÉ, História da Imprensa no Brasil, 1966, p. 234.

42. Jornal do Commercio, $\mathrm{n}^{\circ} 241,31$ ago. 1874.

43. Cabrião, $\mathrm{n}^{\circ}$ 50, 22 set. 1867, p. 394.

44. J. R. de Azevedo MARQUES, Memorial Paulistano para o ano de 1866, São Paulo, Tipografia Imparcial, 1866, p. 129, apud Délio Freire dos SANTOS, Cabrião, edição facsimilar, p. 28.

45. Arlequim, $\mathrm{n}^{\circ} 26,27$ out. 1867, p. 8 .

46. Anotamos, por curiosidade, a quantidade de imigrantes em 1858: 3.127 portugueses, 1.796 alemães, 359 holandeses, 194 belgas, 184 italianos, principalmente napolitanos, vindos pelo porto de Marselha, 144 franceses, 57 americanos para trabalhar na Estrada de Ferro D. Pedro II, 10 ingleses (certamente para trabalhar na estrada de ferro São Paulo-Santos).

47. Jornal do Commercio, Rio, 13 mai. 1859.

48. Jornal do Commercio, $\mathrm{n}^{\circ} 250$, Rio, domingo, 9 set. 1860.

49. Jornal do Commercio, Rio $\mathrm{n}^{0} 318,17$ nov. 1860.

50. Jornal $O$ Futuro, São Paulo, n 20,27 set. 1862, p. 3.

51. Vida Fluminense, Rio de Janeiro, no 348,29 ago. 1874, p. 2.

52. Alberto BASSO, direttore, Dizionario della Musica e dei Musicisti, Torino, UTET, Unione Tipografico-Editrice, 1985. A abreviatura "att." significa que Raquel esteve em atividade, cantando, durante os anos de 1837 e 1838.

53. La Moda, Giornale dedicato al Bel Sesso, bissettimanale, publicado em Milão. Cada edição tem apenas quatro páginas; o cabeçalho é uma xilogravura, que se modifica a cada ano; a coleção da Biblioteca Comunale di Milano possui três volumes encadernados, dos anos 1836, 1838 e 1839. Esta coleção não traz os encartes com desenhos coloridos de moda, que acompanhavam cada número, como indica o expediente. 
54. La Moda, Milão, no 3, 10 gennaio 1839, p. 2.

55. Tradução livre: "A prima donna Raquel Agostini, com a sua voz bela e ágil, se fez aplaudir”. La Moda, Milão, n 3, 10 gennaio 1839, p. 12. Transcrevemos o artigo na íntegra: Anche a Pesaro, come in altri teatri che la prima sera lo spettacolo non ebbe il miglior sucesso. Si diede la Gemma di Vergy, ed il tenore Giampietro Emilio non corrispose in quelle parte. La prima donna Agostini Rachele colla bella e agile sua voce si fece applaudire ed è peccato ch'essa non abbia una maggior forza nel canto. Di sera in sera però, lo spettacolo piacque sempre più, perchè, ridotta la parte del tenore come esigeva la sua voce, egli ha potuto dimostrare il suo talento musicale, e raccogliere dei ben meritati applausi. Forte e ben intonata è la voce del basso Bonafous, ed altro non gli manca che di essere più animato nell'azione.

56. Carlo CINELLI, Memorie Cronistoriche del Teatro di Pesaro dal 1637 al 1897, Pesaro, Nobili, 1898, p. 129.

57. A ópera Gemma di Vergy foi composta por Donizetti em 1834 e não por Pacini, como vem registrado nas Memorie del Teatro di Pesaro; a interrogação ao lado do nome Pacini deve ter sido colocada pelo professor Calcagnini, por ter notado o erro ou porque a palavra não estivesse legível; talvez também não estivessem corretos os nomes do barítono Bonnfox (Bonafoux Orazio, no jornal La Moda), da contralto Pia Lanck (seria a mesma prima donna Lang Paolina do elenco apresentado, acima, pelo jornal La Moda?)

58. A expressão "portuguesa" (de alla portoghese) explica o professor Calcagnini, indica uma pessoa que, graças a um favoritismo ou recorrendo a subterfúgios, consegue entrar em um teatro, cinema, estádio ou em qualquer lugar público de espetáculos, sem pagar o bilhete de ingresso. A origem da expressão, dizem, remonta a um episódio dado em Roma no século XVIII (1700): a embaixada de Portugal junto ao Estado Pontifício tinha organizado em um teatro uma festa à qual só as pessoas de nacionalidade portuguesa podiam entrar sem pagar e sem convite, quando os romanos se apresentaram em grande número declarando-se "portugueses".

59. Tradução livre: "de doces, biscoitos, de grãos-de-bico, sementes e favas".

60. La Moda, Milão, $\mathrm{n}^{\circ}$ 14, 28 fev. 1839.

61. Temperamental e caprichosa como todas as primas donas, La Malibran já havia provocado antes uma rumorosa e retumbante confusão quando interpretou a ópera Maria Stuart, do mesmo Donizetti, no mesmo Alla Scala, em 30 de dezembro de 1835. Cfr. Stanley SADIE, editor, The Grove Dictionary of Music and Musicians, London, Macmillan Publishers, 1980, verbete "Donizetti (Domenico) Gaetano (Maria)", 2, The Achievement of fame. 
La Malibran (Maria Felicia de Beriot) morreu aos 29 anos, no auge de sua carreira, em Boston, em 23 de setembro de 1836, não sem deixar confusões: o marido abriu um processo contra a companhia lírica americana para impedir que a esposa fosse sepultada em Boston e exigiu que seus restos mortais fossem trasladados para a Bélgica, onde residia (jornal La Moda, Milão, $\mathrm{n}^{\circ} 81,6$ out. 1836, p. 321, e n ${ }^{\circ} 84,17$ out. 1836, p. 335-6).

62. La Moda, $\mathrm{n}^{\circ}$ 13, 14 fev. 1839, p. 52.

Antonio Luis Cagnin é professor no Departamento de Cinema, Televisão e Rádio da ECA-USP. 